\title{
China's Dominance of Global Clothing and Textiles: Is Preferential Trade Access an Answer for Sub-Saharan Africa?
}

\section{Mike Morris*}

\section{Globalisation of the textiles and clothing value chains}

A key defining aspect of current globalisation is the production of components in value chains assembled into products for final markets (Dicken 1998). The global clothing and textiles (C\&T) value chains are excellent examples of such complex networks (Gibbon 2003b). In 2003, global C\&T exports were valued at US\$395bn, making it one of the world's most traded manufactured products. Even more significantly, between 1990-2003 exports increased at a compounded annual rate of 6.6 per cent.

This value chain is particularly suited to global production networks as most products can be exported at each stage of the chain, making the sector highly trade intensive and sensitive to a country's trade regime. Furthermore, a large portion of clothing production is labour intensive, requires low skill levels, has low barriers to entry and has been the source of rapid export-led industrialisation in a number of countries (Gereffi and Memedovic 2003). Generally, more complex, higher valueadded tasks remain in developed countries with higher paid skilled labour, while less skilled tasks have moved to low-cost locations mainly in the developing world. In contrast, textiles production is far more capital intensive and therefore developing countries have encountered difficulties in creating backward linkages in the textiles supply chain.

The C\&T value chain is dominated by large retailers, branded manufacturers and marketers who control global production networks and stipulate supply specifications. These retailers are able to wield significant power over manufacturers in terms of price, quality, lead times and raw material inputs. Information flows directly from retailers to clothing manufacturers and textile plants, on patterns, colours and material. Furthermore, these commercial buyers are exceptionally demanding, and are insisting on lower prices, better quality, shorter lead times, smaller minimum quantities and supplier acceptance of as much risk as possible (Flanagan 2003; Kaplinsky 2005).

The retailers' power stems from changing consumer preferences, especially in high-income economies. Consumers no longer want standardised products but demand increasing variety, leading to shorter products seasons, more rapid cycle turnover and smaller minimum orders (Salinger et al. 1999). Furthermore, consumers are more demanding in terms of price; spending smaller proportions of income on clothing but shopping more frequently and buying a larger number of clothing items (Nordas 2004). Coupled with globalisation, this has led to retailers sourcing production from manufacturers in the lowest cost locations in developing economies. These manufacturers either have to absorb the costs and lower their margins, or improve productivity. Also, mergers and acquisitions have led to a greater concentration of retailers in developed economies providing them with the ability to increasingly

IDS Bulletin Vol 37 No 1 January 2006 C Institute of Development Studies 
manage the global supply network. By 2001, the top five retailers in the US accounted for 76 per cent of sales among the top 20 retailers (Weathers 2003). Wal-Mart is the single largest retailer representing 20 per cent of total US demand in the retail sector (Frontline 2004). The UK clothing retail sector is similarly concentrated. According to Gibbon (2001), the top five retailers accounted for 32 per cent of total clothing sales in 2000 , while the top ten accounted for approximately 42 per cent. It is predicted that by 2010 , the top ten retailers will control 25-30 per cent of world textile and clothing trade (Comesa 2004).

For the last quarter of the twentieth century global sectoral trade and production was regulated by the Multifibre Arrangement (MFA), allowing countries to impose quotas on textiles and clothing imports. The MFA's objective was to allow rich countries time to restructure their industries before opening up to competition from poorer countries. Although 73 countries were subject to quotas by the EU, US or Canada, most countries with quota restraints did not use their full quota entitlement. This global regulation system was further complicated by the large importing blocs negotiating separate bilateral arrangements with individual countries or regions, using complex tariff schedules to protect the more capital-intensive parts of the chain, and reduce tariffs generally on labourintensive stages in the production cycle; the aim being to allow their domestic producers to take advantage of outsourced cheap labour for the unskilled labour-intensive part of the production cycle (Kaplinsky 2005).

The consequences were diverse. First, production spread to an ever-increasing number of countries. Second, when key manufacturers reached their quota limits they actively searched for under-utilised quota producer countries to organise garment production therein. Thus, during the 1990s, a rapid process of third-party organising and supply sourcing functions were spread to key garment producers with established access to established markets. Hong Kong, Korean and Taiwanese producers spread their operations to Mauritius, Caribbean and to sub-Saharan Africa. In turn, as they matured, Mauritian garment producers spread their own operations to Madagascar. The Asian producers, especially in Hong Kong and Taiwan, mobilised and coordinated "triangular production networks" covering all the manufacturing stages (Gereffi 1999), i.e. production in a developing economy organised by firms in another middle-income country with products sold to final buyers in a third industrialised economy.

The liberalisation of clothing and textiles has been controversial because the sectors make a substantial contribution to employment in both developed and developing countries. However, manufacturing in most developed countries has severely contracted and changed its focus. Currently, the US, EU and Japan are the largest consumers of textiles and clothing, yet the majority of clothing and textiles in these countries is imported. The Japan Textile Importers Association estimates that 87 per cent of clothes on sale in Japan are imported, while between 1995 and 2002, the US share of world imports of textiles and clothing increased from 14 per cent to 21 per cent, and since January $2001,344,000$ jobs in the industry have been lost (Flanagan 2003). Although the clothing industry in the US and Japan has been decimated, a sizeable clothing industry remains in the EU, especially Southern Europe. The European industry consists of approximately 100,000 firms employing 2.5 million people with a turnover of US $\$ 229 \mathrm{bn}$ (Flanagan 2003).

The top ten clothing exporters (1990-2003) are: China, Hong Kong, Italy, Turkey, Germany, Mexico, France, India, the US and Belgium. China is substantially the world's largest exporter, successfully increasing the value of its clothing exports by 438 per cent from US\$9.7bn in 1990 to US\$52.0bn in 2003. In 1990, China represented only 9 per cent of the world's total clothing exports but by 2003 its share had increased to 23 per cent, and if Hong Kong with 10 per cent of the world total is included, China effectively accounted for one-third of world clothing exports. Although Italy grew clothing exports by 37 per cent, its share of world exports declined from 11 to only 7 per cent, and its 2003 exports of US\$16.2m is less than one-third of China's exports. Mexico and India are the only other countries among the top ten exporters that have been able to increase their world share. Mexico increased its clothing exports from US $\$ 0.6 \mathrm{bn}$ to US $\$ 7.3 \mathrm{bn}$ (an increase of 1,151 per cent), in the process growing its share of the world total from 1 to 3 per cent. India's clothing exports grew by 155 per cent (from US $\$ 2.5 \mathrm{bn}$ to US $\$ 6.5 \mathrm{bn}$ ), at the same time increasing its share of world total exports from 2 to 3 per cent (WTO International Trade 
Statistics in Barnes and Esselaar 2005). However, despite Mexico increasing its exports phenomenally over the 1990s, in the next few years the cold Chinese winds were blowing it backwards. As Kaplinsky (2005) points out:

Between 2000 and 2002, Mexican exports of textiles to the US fell by $\$ 0.89$ bn whilst those of China's rose by $\$ 0.84 \mathrm{bn}$, whilst in clothing the respective figures were a fall of $\$ 1.1 \mathrm{lbn}$ and a rise of $\$ 1.41 \mathrm{bn}$. Not for nothing is there talk in Mexico of "the giant sucking sound" of jobs migrating to China.

China features most prominently with regards to the importation of clothing (HS61, HS62) ${ }^{1}$ into the EU. Imports from China of HS61 total 36,722 billion Euros in 2003; an increase of more than 1,200 per cent since 1999. This is more than eight times the value of imports from Turkey, which itself more than doubled to reach $€ 4,533 \mathrm{bn}$, followed by Bangladesh (€1,769bn), India (€1,073bn) and Romania ( $€ 1,071 \mathrm{bn})$. EU imports from China of HS62 rose by 74 per cent from $€ 3,764$ bn in 1999 to $€ 6,542$ bn in 2003. Imports from Turkey grew by a lesser 62 per cent to $€ 2,863 \mathrm{bn}$, while imports from Romania increased by 66 per cent to $€ 2,763 \mathrm{bn}$ in 2003.

The textiles sector is traditionally far more scaleand capital-intensive, with long lead times, large minimum quantities and less flexibility (Nordas 2004). Given the commodity type nature of much fabric produced for clothing manufacturers, textiles firms in industrialised economies are increasingly producing higher value-added household and industrial textiles - a more technical and R\&D intensive sector, subject to less frequent stylistic changes. Hence most of the relocation of textiles to developing countries has been in clothing fabric. With 16 per cent of the world total, China is the world's largest exporter of textiles. Chinese exports increased from US $\$ 7.2 \mathrm{bn}$ in 1990 to US $\$ 26.9 \mathrm{bn}$ in 2003 (or by 273 per cent), while its share of the world total more than doubled. Italy is the second largest exporter of textile products (US\$13.6bn in 2003 representing 8 per cent of world exports). Hong Kong (US\$13.1bn in 2003) accounts for approximately 8 per cent of total textile exports. China holds the greatest share of US imports (17 per cent), more than doubling since 1997 to reach US\$10,997bn in 2003.

\section{The end of the MFA and the ATC}

In 1994, the General Agreement on Tariffs and Trade (GATT) signatories signed the Agreement on Textiles and Clothing (ATC) committing to phasing out the MFA. On 31 December 2004 the MFA terminated and ended all quotas on textiles and clothing trade between World Trade Organization (WTO) member states. Although 73 countries were subject to quotas by the EU, US or Canada, only China, India and Indonesia consistently filled their quotas ${ }^{2}$ (Flanagan 2003). Hence a major concern is how China will behave in this post-quota world. China has the ability to produce a growing range of items, and has improved its capacity to overcome barriers of international quality standards. The availability of cheap, high-quality fabric, both domestically and in neighbouring Asian countries, is also a strong advantage. China's exports of clothing have already increased to approximately one-quarter of the world total since it joined the WTO in 2001 (de Janquieres 2004), and in the first half of 2004 China sold US\$42bn worth of clothing and textiles (Beware Beijing 2004). Asian prices are declining, while exports are growing (Kaplinsky 2005).

The US International Trade Commission 2004 comprehensive overview of emerging competitiveness trends in the global textiles and clothing industry concluded that China has a major competitive advantage derived from a combination of low wages and high productivity, and the production of highquality and low-cost inputs. China is regarded 'among the best in making most garments and made-up textile articles at any quality or price level' (2004: xiii). Hence it is 'expected to become the "supplier of choice" for most US importers (the large apparel companies and retailers) because of its ability to make almost any type of textile and apparel product at any quality level at a competitive price' (2004: xi).

In the quota-free world, it has been predicted that China's share of world clothing exports will double in less than five years (de Janquieres 2004), and that more than 80 per cent of clothing production may move to China (Beware Beijing 2004). China's share of the US market is predicted to increase to between 65 and 75 per cent post2005 (ATMI 2003). This is based on China's 2002 strategy, which was to drop prices by more than 40 per cent when quotas on a few product lines were removed, thereby undercutting its competitors and 
increasing its US market share. Whether China will have the capacity to follow this strategy for all clothing and textiles categories on all product lines is uncertain.

Although no systematic data is available on the immediate impact of the quota-free world, there are some emerging trends. At the end of January 2005, the Chinese government indicated that imports into the US had jumped about 75 per cent - rising from US $\$ 702 \mathrm{~m}$ in January 2004 to more than US\$1.2bn. In terms of product volume, imports of major clothing products from China jumped 546 per cent. In January 2004, China exported 941,000 cotton knit shirts, whereas in January 2005, it shipped 18.2 million, a 1,836 per cent increase. Similarly, imports of cotton knit trousers were up 1,332 per cent year on year. Given that China ships a large part of its goods through Hong Kong, which would not be reflected in these figures, the real impact may well be understated (New York Times, 10 March 2005).

The data for the first two months of 2005 show that cotton knit shirts and trousers exports to the US were up 2,120 per cent and 1,398 per cent, with nearly 47 million cotton trousers shipped, up from 9 million in February 2004. Chinese Customs data shows similar massive exports jumps to the $\mathrm{EU}$ in January/February 2005, with clothing product exports up 82 per cent to more than US $\$ 1.8 \mathrm{bn}$, while textile exports jumped over 56 per cent to nearly US $\$ 843 \mathrm{~m}$ (just-style.com 1 April 2005). Furthermore, China's April 2005 export data shows that the volume of clothing exports to the $\mathrm{EU}$ and US in April had grown faster (148 per cent) than in the first three months of the year (120 per cent) (Flanagan 2005).

What about the impact on the rest of the developing world's exports? As Kaplinsky (2005) points out, the previous period of export growth by the newly industrialising countries (NICs) was primarily at the cost of domestic producers in the high-income economies being squeezed out of their domestic markets. Consequently, low-income economies in general could simultaneously increase exports to the US and Europe. It was a positivesum game for them. But in this current period, the export growth from a few developing countries will likely be at the cost of other exporters in the developing world - a zero-sum game.

While wages in China are very competitive, they are not the lowest in the world, and there are other reasons for China's export success. First, it is widely believed that the China Yuan is undervalued by around 15 per cent (The Economist 2004) providing a form of export subsidy. Second, the Chinese government subsidises the output of industry by providing cheap capital through non-performing loans, allowing individual firms to invest in the latest technology, develop economies of scale in production, undercut the prices of their competitors and increase their market share (ATMI 2003).

What about the impact of Chinese clothing exports on sub-Saharan Africa (SSA)? Part of the story has to do with hugely increased Chinese imports of clothing into SSA squeezing local producers out of domestic market opportunities. This is well illustrated by the South African case, which unlike other SSA countries, is a middleincome country with a substantial domestic clothing market traditionally well served by the local clothing industry. The vast bulk of clothing production output (around 80 per cent comprising roughly 100,000 jobs) has traditionally been domestically oriented. In 2003, 61.3 per cent of clothing imports for HS62 were from China, with imports increasing by 108.4 per cent in US\$ terms. An increasingly significant proportion of the South African domestic market has been captured by Chinese imports, with potentially serious implications for industrial development and employment. However, the greater impact of China is potentially on SSA's rapid growth of clothing exports. It is to this that we now turn.

\section{AGOA and sub-Saharan Africa}

The Generalised System of Preferences (GSP) programme allows industrialised countries to offer non-reciprocal tariff preferences to developing countries. The African Growth Opportunities Act (AGOA) is a US programme that builds on the existing GSP programme by expanding duty-free benefits to specific product lines from October 2000 to September 2008. On 13 July 2004, the AGOA Acceleration Act extended tariff benefits until 2015, and extends the third country fabric provision originally set to expire in September 2004 until September 2007. This extension is intended to provide business with greater confidence to invest in Africa and provide African producers with a chance of competing with South-East Asian lowcost producers.

To export clothing duty-free to the US under AGOA, countries have to have implemented a visa 
Table I: Clothing exports from Africa to the US and EU (US\$m)

\begin{tabular}{|c|c|c|c|c|c|c|c|c|c|c|c|c|}
\hline \multirow[b]{2}{*}{ Year } & \multicolumn{2}{|c|}{ Kenya } & \multicolumn{2}{|c|}{ Lesotho } & \multicolumn{2}{|c|}{ Madagascar } & \multicolumn{2}{|c|}{ Mauritius } & \multicolumn{2}{|c|}{ South Africa } & \multicolumn{2}{|c|}{ Swaziland } \\
\hline & US & EU & US & EU & US & EU & US & EU & US & EU & US & EU \\
\hline 1990 & 2.5 & 2.5 & 24.5 & 5.6 & 0.4 & 10.8 & 121.2 & 522.7 & 0.0 & 32.3 & 3.4 & \\
\hline 1991 & 4.5 & 6.3 & 27.0 & 18.2 & 0.1 & 15.1 & 97.7 & 536.5 & 0.7 & 72.7 & 5.2 & \\
\hline 1992 & 7.8 & 17.4 & 50.8 & 18.3 & 0.2 & 18.5 & 113.1 & 533.9 & 2.4 & 73.2 & 7.1 & \\
\hline 1993 & 22.1 & 10.3 & 55.1 & 14.7 & 1.5 & 46.3 & 161.2 & 501 & 12.7 & 75.5 & 9.7 & \\
\hline 1994 & 35.2 & 7.1 & 62.4 & 13.5 & 2.8 & 92.6 & 186.2 & 518.8 & 34.7 & 73.4 & 15.5 & \\
\hline 1995 & 34.0 & 6.3 & 61.7 & 12.6 & 6.7 & 122.0 & 190.3 & 573.3 & 55.7 & 66.9 & 11.7 & \\
\hline 1996 & 27.1 & 3.3 & 64.9 & 12.7 & 11.0 & 147.7 & 164.7 & 616 & 60.4 & 67.1 & 11.4 & 0.0 \\
\hline 1997 & 31.3 & 2.6 & 86.5 & 4.5 & 15.3 & 177.1 & 184.4 & 658 & 70.9 & 62.3 & 15.1 & 0.3 \\
\hline 1998 & 33.5 & 2.3 & 100.2 & 0.8 & 22.0 & 218.0 & 233.3 & 693.2 & 78.7 & 69.4 & 16.3 & 0.5 \\
\hline 1999 & 39.3 & 2.5 & 110.7 & 0.2 & 45.7 & 213.9 & 231.6 & 625.2 & 96.9 & 68.3 & 23.2 & 0.6 \\
\hline 2000 & 43.9 & 1.7 & 140.1 & 1.6 & 109.5 & 244.7 & 244.7 & 638.5 & 140.9 & 78.6 & 31.9 & 1.1 \\
\hline 2001 & 64.4 & 1.7 & 216.7 & 3.2 & 178.2 & 238.3 & 238.3 & 591.2 & 173.4 & 69.0 & 48.1 & 0.8 \\
\hline 2002 & 125.9 & 1.1 & 321.0 & 2.1 & 89.4 & 145.6 & 254.4 & 642.3 & 180.6 & 68.7 & 89.1 & 0.2 \\
\hline 2003 & 187.8 & 1.4 & 392.4 & 1.2 & 195.9 & 127.9 & 269.0 & 616.2 & 231.8 & 78.0 & 140.5 & 0.2 \\
\hline 2004 & 277.2 & n.a. & 455.9 & n.a. & 323.3 & n.a. & 226.4 & n.a. & 141.3 & n.a. & 178.6 & n.a \\
\hline
\end{tabular}

Source: Calculated from US ITC, US Department of Commerce, Otexa Eurostat.

Note: US\$ exchange rates based on rates for 31 December in the relevant year. n.a., not available.

system that ensures compliance with the AGOA rules of origin which stipulate that clothing has to be made from fabric, yarn and thread from the US or produced in AGOA-beneficiary SSA countries. However, a special rule applies to least developed countries (LDCs) that have a gross national product (GNP) per capita of less than US\$1,500 in 1998, allowing them duty-free access for clothing made from fabric originating anywhere in the world until September 2007. All AGOA-beneficiary SSA countries qualify for a single-stage transformation, including Mauritius, since October 2004. Only South Africa requires a triple-stage transformation (i.e. yarn to fabric to clothing) in order to qualify under AGOA.

Although in 2001, SSA accounted for less than 1 per cent of global exports of clothing and textiles, AGOA has had a profound effect on the region's clothing industries. Many smaller, higher cost, less developed countries in SSA have been shielded from open competition (Minor et al. 2002), and SSA has therefore been expanding its clothing exports, mainly of low-price basic items such as trousers, T-shirts and sweaters that typically have long production runs, low labour content and few styling changes (US International Trade Commission
2004; Economic Intelligence Unit 2004). The production and export of clothing is concentrated in a small number of SSA countries: Kenya, Lesotho, Mauritius, Madagascar, Swaziland and South Africa, accounting for about 90 per cent of African clothing exports (Gibbon 2002, 2003a). In comparative terms, the largest SSA suppliers' exports were worth US\$3bn; miniscule compared with the US's US\$453bn imports from China (Gibbon 2002).

As Table l shows, Lesotho is the largest SSA exporter of clothing to the US, exporting US\$455.9m in 2004. Mauritius has traditionally been the second largest exporter to the US but in 2004 was overtaken by Madagascar whose clothing exports to the US jumped from US\$195.9m to US $\$ 323.3 \mathrm{~m}$. Due to the impact of AGOA, both Kenya and Swaziland have doubled their clothing exports to the US in the past few years. These six countries collectively make up the vast bulk of textile and clothing exports from SSA to the US; in 2003 collectively, US $\$ 1,602.7 \mathrm{~m}$ out of a total SSA export of US $\$ 1,757.2 \mathrm{~m}$. In 2003, Mauritius was by far the largest African exporter of clothing to the EU (US\$642m), followed by Madagascar (US\$146m) and then South Africa again in third place (US\$69m). 
Table 2: AGOA qualifying as share of total clothing exports to US, 2001-04

\begin{tabular}{|c|c|c|c|c|c|c|c|c|}
\hline \multirow[t]{2}{*}{ Country } & \multicolumn{2}{|c|}{2001} & \multicolumn{2}{|c|}{2002} & \multicolumn{2}{|c|}{2003} & \multicolumn{2}{|c|}{2004} \\
\hline & (US\$m) & (\%) & (US\$m) & (\%) & (US\$m) & (\%) & (US\$m) & $(\%)$ \\
\hline Lesotho & 129.2 & 60.1 & 317.7 & 98.9 & 372.6 & 94.9 & 447.6 & 98.2 \\
\hline Madagascar & 92.1 & 51.8 & 75.4 & 84.4 & 186.3 & 94.9 & 314.5 & 97.3 \\
\hline Kenya & 51.7 & 80.0 & 121.3 & 96.6 & 176.2 & 93.9 & 271.5 & 97.9 \\
\hline Mauritius & 38.9 & 16.3 & 106.5 & 41.8 & 135.0 & 50.2 & 147.8 & 65.3 \\
\hline Swaziland & 8.2 & 17.1 & 73.7 & 82.7 & 126.9 & 90.2 & 175.6 & 98.3 \\
\hline South Africa & 30.4 & 17.4 & 85 & 46.9 & 126.6 & 54.5 & 114.7 & 81.2 \\
\hline
\end{tabular}

Source: Calculated from US Department of Commerce, Otexa.

The critical issue in this rapid industrialisation process is two-fold. First, the impact of AGOA on the industrialisation process in these countries is clear from the rapid take-off of total clothing exports post-2001. Second is the impact of exports under AGOA qualifying rules from these countries (Table 2). For most SSA countries, the vast bulk of their clothing exports to the US have been via AGOA's preferential trade access which has been the principal mechanism stimulating and maintaining the relatively major increase in clothing production in these countries. The impact that this clothing-based industrialisation process has had on creating wage employment and reducing poverty in these poor SSA countries is hugely significant.

The contrast to this trend have been Mauritius and South Africa, which up until 2003 only exported a maximum of 50 and 55 per cent respectively through AGOA because of the triplestage transformation rule. This trend starts to change dramatically in 2004 and the proportion of AGOA clothing qualifying exports from South Africa as a percentage of total clothing exports rose dramatically to 81 per cent, while Mauritius jumped to 65 per cent. In both cases, but more significantly in the South African case, this proportional increase is a direct result of the decline of total clothing exports to the US, principally because of the near total collapse of its non-AGOA clothing exports. Mauritius still managed to maintain a small upward trend in its AGOA-related exports but in the South African case AGOA-related clothing exports declined as well. Quite clearly, both countries were severely hit by the end of the MFA and the rise of China. In the South African case this was exacerbated by the rapid strengthening of the Rand, which made it difficult to compete even under AGOA tariff protection. These clothing exporters are only currently viable as a result of preferential access to the US through AGOA qualification.

SSA is not a low-cost location, for labour costs are relatively high, productivity is low, lead times are long and non-labour input costs are higher than in Asia. Further disadvantages include logistics (transport costs and longer lead times), unreliable telecommunication systems and inadequate physical/technical infrastructure. Many argue that SSA firms will have difficulty competing in a quotafree environment, and it is unclear whether AGOA and EU preferences will be sufficient to keep the industry competitive outside of the man-made fibre and woollen clothing sub-sectors where SSA is considered competitive and where US import duties are high (Economic Intelligence Unit 2004).

Table 3 shows the US customs duty rates and China-US quota costs between synthetic and cotton products. Exports to the US have been protected by two factors: the percentage duty rate (tariff) and the US dollar cost of buying import quota. With the end of the MFA (and hence quotas) the latter should disappear and no longer be an add-on cost to Chinese exports. Then the only defence countries with preferential agreements have is the duty rate imposed by the US government. This is clear from Table 3, especially in the case of woven men's trousers and women's dresses with tariff protection of only 10.3 per cent and 8.4 per cent respectively. For synthetic sweaters (32 per cent) or men's suits (27.3 per cent), this still maintains a substantial rate of protection against cheap exporting 
Table 3: US customs duty rates and China-US quota costs

\begin{tabular}{lll}
\hline Item & General duty rate (\%) & 2003 quota price/dozen (US\$) \\
\hline Cotton garments & & \\
$\quad$ Knit men's shirts & 19.7 & 32.50 \\
$\quad$ Knit T-shirts & 16.5 & 32.50 \\
$\quad$ Woven men's trousers & 10.3 & 39.00 \\
$\quad$ Woven women's dresses & 8.4 & 30.50 \\
Synthetic knit/woven garments & & \\
$\quad$ Knit women's skirts & 16.0 & 35.00 \\
$\quad$ Knit sweaters & 32.0 & 23.50 \\
$\quad$ Woven men's suits & 27.3 & 90.00 \\
$\quad$ Woven women's dresses & 16.0 & 37.00 \\
\hline
\end{tabular}

Source: Calculated from General US duty rates: Harmonised tariff schedule; 2003 reference prices for Chinese/US quota www.chinaquota.com

competitors. SSA producers have thus to be wary of depending on exports of cotton products to the US which have low tariff duty rates. In this respect the existence of a substantial and sophisticated synthetic textile industry in South Africa may present significant value chain opportunities for SSA producers.

There still remains a medium- to long-term problem for SSA producers that are currently exempt as low-income countries under AGOA from having to source their fabric from the region, for this rule is set to expire in 2007, and then the rest of SSA countries will find themselves in the same position as South Africa. US buyers are sure to be wary of continuing their sourcing from SSA (especially for cotton products) under these conditions as there is no guarantee that these producers will be able to either maintain quality standards or be price-competitive. A key policy issue is therefore how to develop the cotton products value chain in order to reap systemic competitive benefits along the chain. At present the bulk of SSA cotton is exported in an unprocessed form, for example from Zambia and Malawi, which is then imported back into SSA as fabric for manufacturers exporting clothing under AGOA. Important conversion stages within the cotton pipeline are thus lost to the region. South Africa, with its well-developed textiles sector, is perhaps therefore in an ideal position to establish itself as the textiles supply base for SSA using regional cotton inputs.

\section{Conclusion}

The international clothing and textiles industries are hyper-competitive. Preferential trade access through AGOA has had a major impact on a significant number of poor SSA countries which have managed to significantly expand their clothing industries. The impact on employment, and hence poverty reduction, in Lesotho, Madagascar and Kenya, of being able to be locked into captive clothing value chains has been hugely significant. But the threat of China looms. We still do not know the impact of the Asian clothing producers in a post- MFA world on SSA clothing exports. A reversal of these industrialising trends (as the South African case seems to be potentially illustrating) will be catastrophic.

South Africa is not solely dependent on exporting through AGOA. It is the only SSA country with a large middle- and high-income domestic market, previously protected from international competition, and until recently sustaining a substantial domestic clothing industry, employing over 100,000 workers. Hence, the trend towards substantial Chinese imports has severe implications for its clothing industry.

Four policy conclusions flow from this analysis of the nature and trajectory of SSA's clothing and textile industry. First, preferential trade access (AGOA) is essential for "competitively disadvantaged" poor SSA countries to enter global value chains, to industrialise, to expand employment and to reduce poverty. However, the 
preferences in question are not so much against competitors in the high-income economies (particularly with respect to the US) but in relation to Asian competitors in general and Chinese competitors in particular (Kaplinsky 2005). Second, preferential market access alone is inadequate, particularly in a world characterised by rapid technical change and changing patterns of production and trade. It is also necessary for SSA countries to upgrade production capabilities and competitiveness, on an ongoing basis. If their enterprises are unable to internalise manufacturing excellence to meet the required critical success factors, they will eventually drop out of the global C\&T textile value chains. Third, almost certainly SSA will have to develop its upstream cotton, yarn and fabric linkages, and create greater clothing and

\section{Notes}

* I am indebted to comments and assistance from Justin Barnes and Raphael Kaplinsky and help with data from Peter Gibbon and Myriam Velia. See also Morris et al. (2006).

1. HS61 is 'knitted and crocheted', while HS62 is 'not knitted and crocheted'.

2. This created a domestic "quota price" expressed as an "add on" to the Chinese manufacturers' selling price into

\section{References}

American Textile Manufacturers Institute (ATMI) 2003, The China Threat to World Textile and Clothing Trade, www.atmi.org (accessed November 2005)

Barnes, J. and Esselaar, J., 2005, Customised Sector Programme: Clothing and Textiles Draft Research Report, Benchmarking and Manufacturing Analysts for the South African Department of Trade and Industry

Beware Beijing, 2004, Beware Beijing When Its Freed From Quotas Cage, unknown

Comesa, 2004, Impact on COMESA's Textiles Exports Under AGOA of the End of Multilateral Quotas Under the Agreement on Textiles and Clothing: Can African Textiles Industry Survive and Grow in Post ATC World?, Lusaka, Zambia

de Janquieres, G., 2004, 'The textile revolution', Financial Times, 26 July, London

Dicken, P., 1998, Global Shift: Transforming the World Economy, London: Paul Chapman

Economic Intelligence Unit, 2004, 'Africa consumer goods: clothing industry is shrinking', The textile synergies in the region since it is unlikely that the derogation on the sourcing of inputs will be sustained for many years. Here, there is possibly scope for regional integration since some economies in the region (notably South Africa) have the potential to act as a transformer of regional natural fibres into the intermediate textiles which are required to manufacture finished clothing products. Finally, there are particular challenges for both the users and creators of preference regimes to pay attention to the balance between natural and synthetic fibres. At present, preferences are highest in the synthetic fibres which, outside of South Africa, are not widely produced in SSA and lowest in the natural fibres where SSA farmers have most potential and where multiplier effects are most marked.

export markets, because the Chinese government sold the quota to the highest bidding enterprises. The quota price therefore expressed the supply and demand for quota for particular categories of product, and normally increased during the year as the amount of unused quota fell. Reference quota prices are normally averages for a given year.

Economist, 27 April, London: American International Group

The Economist, 2004, 'A fair exchange?', Survey: The World Economy, 30 September, print edition

Flanagan, M., 2005, Has Quota Abolition Really Been So Bad?, www.just-style.com (accessed 4 July 2005)

Flanagan, M., 2003, Clothing Sourcing in the 21st Century, The 10 Lessons So Far, www.JustStyle.com (accessed November 2005)

Frontline, 2004, Is Wal-Mart Good for America: An Interview With Gary Gereffi, 16 November 2004, www.pbs.org/wgbh/pages/frontline/shows/walm art/ (accessed November 2005)

Gereffi, G., 1999, 'International trade and industrial upgrading in the clothing commodity chain', Journal of International Economics, Vol 48: 37-70

Gereffi, G. and Memedovic, O., 2003, The Global Clothing Value Chain: What Prospects for Upgrading by Developing Countries?, Vienna: UNIDO

Gibbon, P., 2003a, 'AGOA, Lesotho's clothing miracle and the politics of sweatshops', Review of African Political Economy No 96 
Gibbon, P., 2003b, 'The African Growth and Opportunity Act and the global commodity chain for clothing', World Development, Vol 31 No 11

Gibbon, P., 2002, 'South Africa and the global commodity chain for clothing: export performance and constraints', mimeo, prepared for Centre for Development Research, Copenhagen

Gibbon, P., 2001, 'At the cutting edge: UK clothing retailers and global sourcing', Working Paper Subseries on Globalisation and Economic Restructuring in Africa 14, CDR Working Paper 01.4, Copenhagen: Centre for Development Research

Kaplinsky, R., 2005, Globalization, Poverty and Inequality: Between a Rock and a Hard Place, London: Polity Press

Minor, P.J., Velia, M. and Huges, J.K., 2002, 'Assessing the potential for South African clothing exports to the United States and how the DTI and the South African clothing industry could best ensure that this is maximised', Research Report to the South African Department of Trade and Industry (DTI), mimeo, Durban: School of Development Studies, University of KwaZulu-Natal

Morris, M., Barnes, J. and Esselaar, J., 2006 forthcoming, 'Globalisation, the Changed Global Dynamics of the Clothing and Textile Value
Chains and the Impact on Sub-Saharan Africa', draft chapter in O. Memedovic (ed.), Global Value Chains and Production Networks: Prospects for Upgrading by Developing Countries, Vienna: UNIDO

Nordas, H.K., 2004, 'The global textile and clothing industry post the Agreement on Textiles and Clothing, WTO Discussion Paper 5, Geneva: WTO

Salinger, B.L., Bhorat, H., Flaherty, D.P. and Keswell, M., 1999, 'Promoting the competitiveness of textiles and clothing manufacture in South Africa', African Economic Policy Discussion Paper 32, Cambridge, MA: Associates for International Resources and Development (AIRD)

US International Trade Commission, 2004, Textiles and Clothing: Assessment of the Competitiveness of Certain Foreign Suppliers to the U.S. Market, Vol I, Investigation No 332-448

Weathers, N., 2003, 'Marketing strategy to enhance the competitiveness of African clothing firms under the African Growth and Opportunity Act', draft mimeo, Philadelphia: Philadelphia University, research sponsored by the Lindback Foundation

WTO International Trade Statistics, 2004, www.thedti.gov.za/econdb/raportt/rapmenul.ht $\mathrm{ml}$ (clothing and textiles data pp. 155) 